\title{
BURKINA FASO: An Inquisition of Ansaroul Islam Insurgency in West Africa and Its Emerging Threat
}

\author{
Frederick Appiah AFRIYIE
}

\begin{abstract}
Burkina Faso has suffered the numerous cruelties of terrorism, Ansaroul terrorism inclusive. Prior to their dormancy, two popular terrorist groups, the Ansaroul Islam and Jama'a Nusrat ul-Islam wa al-Muslimin (JNIM) had existed as the principal terrorists in Burkina and adjacent political entities. In some past years, the masters who had been behind the mask of violence in Burkina has been the Ansaroul. Believed to belong to a jihadist sect of the Mali rebellion and as well traced to the Al-Qa'ida, the Sahel area hosted this popular terrorist. The group has been responsible for far-reaching radicalism and cutting-edge violence within the Sahel, spreading its influence on the neighboring Afro Islamic countries, especially Burkina Faso. Against this background, this paper conducts an examination of the Ansaroul Islam activities. Inferences are drawn from secondary sources, thus articles which has already an about the subject of interest. The study will route audiences through analysis of literature to present the implications of related policies, their significance and consistency in giving a deadly blow to terrorism in the said region. However, the unrevised terrorism policies which do not align with provisions in a holistic international framework lacks the ability to break the shackles of terrorism on Africa and the global anti-terrorist society. Efforts to combat terrorism will, in the bosom of weak policies, remain infidel to peace.
\end{abstract}

Keywords: Inquisition, Ansaroul Islam, Emerging West-Africa, Insurgency.

\author{
Frederick Appiah AFRIYIE \\ ZHONGNAN University of Economics \\ and Law, China \\ E-mail: kaaf0712@gmail.com \\ Conflict Studies Quarterly
}

Issue 29, October 2019, pp. 3-16

DOI:10.24193/csq.29.1

Published First Online: 04/10/2019

\section{Introduction}

The few past years have witnessed an upsurge in the activities of terrorists in Burkina Faso. This contemporary chronology of terrorism incepted with the abduction of two international aid volunteers in December last year and a miner from Canada. The later was found lifeless. The country has been recording consistent terrorist events for 
quite a long period. In 2014, President Blaise Compaoré was ousted through a prevalent insurgency. This event chalked the gradual demise of the Burkina security system, birthing an era of brutality and chaos under a broad umbrella of three-year prolonged terrorism since 2016. Cases within the time stretch have been over 200. Most people are not amazed by the sudden uprising since speculations hover around that President Compaoré negotiated with terrorist groups in his attempt to free the country from insurgent acts. In addition, there is an influx of terrorist groups from the sister country Mali, into Burkina Faso, strengthening the terrorist base of the later. The Soufan Group (2019) have concluded that terrorism seems to flourish in West Africa, owing to its social, economic and environmental conditions which allow for easy absorption of youth into the groups.

Burkina Faso is an inland country, bordered by three coastal countries, Ghana, Benin and Togo. These terrorist activities in Ghana have stimulated a growing concern for the security of her neighbors. From 2015 up till now, the insurgent activities have not been able to diffuse to these landmarks even though far-reaching implications alight on the front doors of the countries. Ghana, Togo and Benin have not been treated by jihadists as Burkina, regarded as the anchorage for networks like Al-Qaeda and related groups, following their unpopularity in Mali. Their presence in Burkina has been alarming and their activities are shockingly accelerating. The past few months have seen terrorist triggers in the east of Burkina, a region in close proximity with Togo and Benin, rekindling the uncertainties of jihadist movements traveling downcoast. Yet in Ghana, the related consequence of Burkina terrorism is yet to approach the country, according to the National Disaster Management Organization. According to BusinessDay (2019), the Bawku northeastern part of Ghana has received about 500 people (children inclusive) as refugees in the area.

Two principal areas in Burkina Faso has been suffering at the hands of terrorists. These are the northern and the eastern sectors of the country, with the eastern sector experiencing intensified terrorist activities. The northern cluster of terrorists has been responsible for numerous terrorist events. These include, but probably unlimited to the Splendid Hotel attack and the Cappuccino in Ouagadougou. The latter occurred in January 2016, ending with over 50 casualties and 30 lives lost (The Soufon Group, 2019).

Burkina Faso's Ansaroul Islam can be described as a domestic group originating from the Sahel area. It surfaced in 2016 and has since been battling with the peace of Burkina Faso till date, affecting the formation of several other similar rebellions. According to the Human Rights Watch (2019), two major groups parent the various terrorist groups in Burkina, the Ansaroul Islam being threatful amongst them. It is believed by the Watch that, both Al-Qaeda in the Islamic Maghreb (AQIM) and the Islamic State in the Greater Sahara (ISGS) have through the Ansaroul and minor terrorist groups been responsible for raids on police, gendarme and army posts, as much as civilian attacks which have taken lots of lives, incapacitated others and inflicting injuries on civilians. 
Statistically, more than half of terrorist activities between 2016 and 2018 in Burkina Faso can be traced to Ansaroul Islam. This gives the group a leading role in the inventers of the unstable northern Burkina environment. The region receiving great impact from the violent events of the Ansaroul was the Soum province, with its center Djibo suffering most. The province recorded about 64 raids, claiming over 40 casualties in 2018. The tendency of the Ansaroul Islam raiding civilians was high. Mainly, slightly more than half of their attacks target civilians. This record represents the second-highest of such in Africa to northern Mozambique and the highest percentage in the Sahel area. The Soum province has ended school activities in more than 300 schools and over 100, 000 families have abandoned their unsafe homes, due to militant Islam attacks. Interestingly, Pauline Le Roux (2019) reveals that records show the Ansaroul has staged 16 vicious activities with just about 7 casualties.

Terrorism in Burkina Faso has not only been thee doing of the Ansaroul militant Islamists. The JNIM sub-grouped, believed to have been supported by Al-Qaeda has as well been responsible for numerous attacks in the Sahel region, spreading their tentacles to Burkina Faso. Consequently, in recent times, the group's super terrorist events have acquired international recognition in the global terrorist community and infamy on the international security front. Radical Islamist activities of the JNIM takes the form of raids on security posts, peacekeepers and hotels which hosts visitors from the western world. There has been widespread abduction of aid workers, diplomatsthe and tourists from American and European origin in the Sahel region, for which the JNIM is responsible (Donati,2019). The recent attack on the French embassy in Ouagadougou in March is considered to be a handiwork of the JNIM as it bloated the newspapers all over the country and worldwide. In addition, the group was also responsible for the attack on the national army headquarters, taking 8 lives of soldiers. Following these terrorist events, the United States government has responded by enlisting Ansaroul and JNIM as one of the world's treacherous terrorists.

\section{Methodology}

This paper considers examining the emerging Ansaroul Islam terrorist groups in recent times through critical analysis. The study will detail its observations according to the likenesses and differences in the various terrorist organizations, their operations and specific aims they ought to achieve.

Arguably, this study can follow specific methods but most popularly through the use of qualitative analysis of evidence from trivial events, as agreed by Burnham, Lutz, Grant, \& Layton-Henry (2008). In accordance with the arguments of Collier (1993), that "this focus on a small number of cases is adopted because there are relatively few instances of the phenomenon under consideration that exhibit the attributes of interest to the analysis", the qualitative method, applies. It is apparently impossible to access 
the influential people and even the members of these terrorist groups. This leaves the research with no choice than to depend on free data which is published for public use. The study therefore draws information on these two terrorists' groups from primary sources as archives, media, terrorist watches and state reports. To support this, tentative information is as well obtained from secondary sources such as other articles. Lijphart (1971) gives a preamble in relation to the time, efforts and capitals resources and conclude that examining a few cases thoroughly is quite better than statistics from a chunk of cases which may attract lesser funding and focus.

\section{Conceptual and Theoretical Framework}

Terrorism defies precise definition, especially among institutions and states which deal with and use the term frequently and even among the terrorist's community (Tuman, 2003). The political, emotional and personal dimensions of the concept make it difficult to identify who a terrorist is. In fact, a hero from another country can be an insurgent in another country. Drawing insights from the principles adopted by Boko Haram to operate, this study will consider Terrorism as the "use or the threatened use of force designed to bring about a political change (Twum, 2003)". Again, this study defines terrorism in the religious context as "A type of political violence motivated by an absolute belief that an otherworldly power has sanctioned and commanded terrorist violence for the greater glory of the faith. Acts committed in the name of the faith will be forgiven by the otherworldly power and perhaps rewarded in an afterlife. In essence, one's religious faith legitimizes violence as long as such violence is an expression of the will of one's deity" (Martin, 2015, p. 130) since the primary terrorist groups focused in this paper's discussion connect their actions to their religious beliefs. The theory that backs is study is the relative deprivation theory as proposed by Gurr (1970), even though there is a host of lightly tested hypothesis which can support the study. this theory will be used to trace the roots of expanded ferocity of the rebellions as Ansaroul Islam. According to Gurr (1970), radical disruptions in the political discourse of a country may be linked to the human perception of being starved one's due merit or right. Again, the sentiment is aggravated by the contrasting lives of others, supposed to be in an optimal condition than the terrorists, planting in them an ever-growing motive for their acts. In the words of Gurr (1970), "the potential for collective violence varies strongly with the intensity and scope of relative deprivation among members of a collectivity" (p. 24) as "men are quick to aspire beyond their social means and quick to anger when those means prove inadequate but slow to accept their limitations" (p. 58).

\section{The Emergence of Ansaroul Islam}

Discussions in this section will focus on the origin, organization, leadership and the funding of the Ansaroul Islam. The various methods adopted to operate, and potential 
targets will as well be highlighted in this section. In addition, the various global networks of Ansaroul Islam will be highlighted.

Ansaroul Islam can be described as a domestic terrorist group and fist of its kind in Burkina Faso. There had been numerous staged terrorists' activities far before the inception of Ansaroul Islam in Burkina Faso, from different radical jihadists. In 2016, Ansaroul Islam identified themselves as a fresh terrorist group, following the attack on a Burkinabe-French army camp in the last month of that year. The Islamic principle of universal brotherhood and equity was extended to a more radical form through the teachings of Boureima Dicko in 2012. Going back into history, the Ansaroul Islam seeks the awakening of an ancient Burkinabe empire which had long been evaporated by the presence of the French in the 1800s. Regarding themselves as the resurfaced Djeelgodji, the Ansarouls stages most of their operations in Mali and Burkina, believed to be the ancient home of the Djeelgodji. Those who suffer at the hands of these insurgents are poor civilians and innocent security officers from the Burkinabe security sector and the anti-terrorist units of the French government on visits. Activities of the Ansaroul Islam are pronounced in the Soum province, including some regions in Mali and along the borders between Burkina and Mali. Ansaroul Islam has principally occupied two areas of Boulkessi and N'Daki in Mali. According to Nsaibia, Heni, and Caleb Weiss (2018), the strategic locations of this town along the Burkina Mali border makes it possible to alternate terrorist activities in both countries. In addition to the two towns, there are prominent terrorist settlements in Fhero and Foulsare. The post-assault period in early 2017 in Foulsare led to the disintegration of the insurgents into smaller units that scattered into far away parts of the Suom province.

\section{Leadership}

The leadership of Ansaroul Islam has not had many successions. There have been only two leaders, believed to be the founder and his brother. The founder and first leader of Ansaroul Islam is Boureima Dicko (December 2016 - May 2017) who was succeeded by his younger brother after his death. The second and current leader of the Ansaroul Islam believed to be the brother of the founder of this group is Jafar Dicko, who started reigning in May 2017. It all began with radical Islamic teachings and later escalated to revolts after the capture of the founder, Dicko by the French anti-terrorist group in the later part of 2013. Widespread radical teachings in smaller social gatherings and on media channels led to the establishment of Al-Irchad Network. On his release by the French group, the ignition to revolts turned on automatically with the smaller holding Ansaroul Islam group in the Mondoro forest of Mali. This is where it started, and when he died naturally in May 2017, a blood successor emerged to preserve a psychopathic legacy (Center for International Security and Cooperation [CISAC], 2018). 


\section{Targets and Tactics}

The targets who have suffered the hands of Ansaroul Islam has been mainly the security forces (police and army) of Burkina Faso and the French anti-terrorist bases. In addition, Nsaibia, Heni, and Caleb Weiss (2018) retorts that Ansaroul Islam disrupts society by their raids on educational and government facilities within the Sahel area. There have been several executions of civilians at the hands of Ansaroul Islam, promoting the life of fear and panic within the Sahel region. In most cases, victims who fall to the religious scandals of these militants are either witnesses to security forces or persons who have closer links with the Burkina government. The Human Rights Watch (2018), agrees that targets may be those who disagree with the ideologies of deep jihadism. Prior to the year 2017, weapons which were used by the insurgents were smaller firearms in its raids. After the interception of JNIM, passing knowledge and skills to Ansaroul, the latter upgraded their arms base to the stocking of IEDs. In addition to raids and killing of civilians, there have been numerous robbery and theft cases of Ansaroul Islam (Nsaibia \& Weiss, 2018).

\section{Source of financing}

Every organization, be it socially accepted or otherwise requires resources to achieve specific goals. A superior terrorist group called Ansar Dine has supported Ansaroul in different forms, ranging from technical support to resource provision. Other supporters include the MLF and Katibat Serma. It has come to light that, the group contacts Abu Bakr al-Shinquiti, leader of another militant group AQIM. This group has reportedly provided human and financial resources towards the establishment and growth of Ansaroul Islam (CISAC, 2018).

\section{International Connection}

There is a higher global tendency of minor militant groups associating themselves with rooted groups, have reported that an associate of Ansaroul founder Boureima Dicko is Amadou Kouffa, an emir of the Macina Liberation Front (MLF). From this emir, Ansaroul has received all kinds of support in its terrorist activities, especially at the inception phase of the group. Another associate identified is the Katibat Serma of the Ansar Dine group, a militant unit which collaborated in the raid on Nassoumbou in late 2016 (CISAC, 2018).

Some subgroups of the Ansar Dine consolidated to establish Jamaat Nusrat al-Islam wal Muslimeen in March 2017. Popular among these subgroups was MLF. There is uncertainty regarding the links between the JNIM and Ansaroul Islam even though the former allegedly supports the operations of the later with skills enhancement and resources, more especially with the utilization of IED weapons. There is also anther controversy regarding the group responsible for a series of attack staged in 2017.Center for 
International Security and Cooperation (CISAC) (2018) retorts that local news exposes the Ansaroul Islam to be responsible for about six attacks. The story later changed as JNIM announced its full handiwork of these raids.

Another network associated with Ansaroul is Al-Qaeda. In effect, Ansaroul seems to be more of a representation of Al-Qaeda in the Sahel African region. Smaller militant groups liaise with Ansaroul, a group believed to be in direct contact with the Al-Qaeda network. According to Center for International Security and Cooperation (CISAC, 2018), Al-Qaeda had a hand in the formation of Ansaroul as their Senior AQIM commander Abu Bakr al-Shinquiti helped built Ansaroul through militant enlisting and training.

\section{Why radical groups and terrorism is taking root in Burkina}

Burkina Faso has over the past few years become and open and fertile platform for breeding terrorism and activities of radical Islamist. This is due to some factors, grouped under 'push' and 'pull' factors. In the first place, push forces include structural circumstances which direct people to accepting the radical jihadist philosophy, later resulting in excessive violence in Burkina. After an assessment of one's environment, certain conditions including corruption and impunity, economic hardships, poverty, higher rates of unemployment and higher costs of living, the mindset and cognitive perceptions of the individual is likely to develop resentment for the nation.

Secondly, the pull factors are embedded within the benefits one ought to enjoy as being part of an insurgency group. They are packages which serve as a magnet to dismayed youth. Joining militant groups helps some individuals to fulfill their dreams of giving everyone an equal social opportunity, brainwashed with radical Islamic teachings and solving domestic economic inefficiencies. These pull factors stimulate the interest of people in violent jihadist movements (Antwi-Boateng, 2017).

\section{Push Factors}

\section{Corruption and Impunity}

Quite a lot of the sub-Saharan countries, including Nigeria and Ghana face the national challenge of corruption within several public offices and institutions. Burkina Faso is of no exception to this challenge (Loada \& Romaniuk, 2014). Various government agencies in Burkina and civil society organizations have reported an increase in corruption cases. Not-for-Profit organizations have also recorded high profile corruption activities in the country. On sectoral basis, corruption has shown its face in agencies as the civic promotion, justice departments, health sector, revenue departments and most severely, in the security services of the country.

Empirically, the Réseau National de Lutte Anti-Corruption (REN-LAC - National AntiCorruption Network) observed corrupt conducts in 2011. Crimes do not only take 
physical form but economic and political as well. Impunity has been on the rise the resultant effect was digging out the radicalism in people, which the Burkina government has been aware since 2011 .

The Burkina government seemed to be playing with the incidence of corrupt acts in the country. Evidently, the Burkina Prime Minister on consistent occasions admit to a corruption filled government and promises to address the menace. The leaders of the country should have long known that their tortoise movement on the corruption issue would wake the religiously just lions to dictate their strategies for them.

As much as the government has been dragging her feet on corruption, the courts are not strong enough to prosecute cases on corruption. As observed in the 2011 state of corruption reports, impunity was on the rise, following the broken judicial system. The judicial instruments laid to address public sector corruption and misconduct has not been effective and this breeds corruption the more.

Impunity has slapped justice with incompetency and this is birthing a chaos atmosphere where every young strong militant is an Attorney. There is not the duality of 'mob justice' and 'incivism', reigning the streets of Burkina Faso in the form of intense civil unrests, a new order likely to chalk violence in the history of Burkina Faso. In effect, ordinary citizens deprived of what is fundamentally due them are embracing terrorism as the sole way of overcoming the corruption that breeds their afflictions. Clearly, this circumstance fuels the willingness of people to side with Ansaroul Islam when joined with the radical teachings on social equality. Citizens are redirected to believing that the resolution to corruption and impunity is violent religious justice (Loada \& Romaniuk, 2014)

\section{Rural Poverty}

The various factors which join forces to drive people to act violently in the name of social justice by means of religious radicalism are the marginalization, deprivation from due basic services and economic hardships. The poverty margin between the urban regions and the rural regions of Burkina Faso is wide enough to declare poverty as a resident of rural Burkina. But poverty is concentrated in the northern and eastern parts of the country, introducing the perception of neglect to the people in these areas by the government they have so voted into power. The abysmal economic atmosphere in the northern enclaves of the country makes the region prone to Ansaroul influence. The Suom province in the northern part of the country is made up of Fulani tribe, a large ethnic group of people in the north but smaller in a national context. In the land of the Fulani, there is no low provision of social services and the lot of them feel dejected at the national level. Inferiority complex is widespread amongst the northern Fulani population, stimulating internal hatred for other tribes. In the Suom province, there is the struggle for traditional dominion owing to the absence of religious order. These conditions within the northern sector prepared the region as an environment favorable 
for Dicko to recruit masses into his terrorist group. In detail, there are defective legislative, economic and basic social systems. These conditions did not just by themselves introduce terrorism into the region. Rather, it provided a fertile ground where the joint force of periodically unstable environment and the tactical strategies adopted by the Ansaroul thrived. In addition to these, there is widespread robbery, theft and burglary cases in the north. These will intend mandate individuals to help restore social order to the environment. In Fada N'Gourma, culprits are prosecuted as citizens are encouraged to help in the cases of offenders. However, these witnesses receive little to no protection from security (Loada \& Romaniuk, 2014).

\section{High Cost of Living}

It has not only been the widened poverty gaps between the rural and urban parts of Burkina causing people to team up as militants. The country has suffered the high costs of living, a condition which does not match up with the incomes of the citizenry. Evidences span from the 2008 food shortage which generated some disturbances in the country. The Burkinabe government attempted to minimize the problem through diversified means but still did not work to the grassroots poor. This contributed to the lost confidence in the government even though there has been current redress of the living costs by relocating of budgets to social services. It is widely believed to be domestic and external influences which are causing living inequalities in the country and this is well known to slip the control of the government of Burkina Faso (Loada \& Romaniuk, 2014).

\section{Unemployment}

Idle youth of every economy would like to find something to occupy them. Several counties have recorded an increase in socially unaccepted occupations adopted by the youth when there are higher rates of unemployment. Higher rates of unemployment and mostly, underemployment has been a shackle around the neck of the Burkinabe economy, availing terrorism as an option to the idle hands, usually in the slum parts of cities. This condition may not be completely able to drive the youth to join terrorists. Amid their financial instabilities, most youths are invited to join the terrorist groups through monetary offers and other incentive packages. In effect, attractive offers from the terrorist groups capitalize on the economically distressed environment to recruit the youth of the northern and eastern parts of Burkina (more especially from the Fulani subgroup to fight in Mali and Burkina) (Loada \& Romaniuk, 2014).

\section{Imploring to local grievances}

One of the major pull factors which attract individuals to join terrorist movements is the satisfaction that radical teachings give to the local grievances in Burkina Faso. In the media and community teachings of radical Islam, teachers seem to have fair judgment 
and practice of what they preach. These teachers are distinguished personalities who speak against social inequalities and economic disorders in the country. The teachings as well center on principles of equity and fair distribution of resources, discarding the widened livelihood gaps and class stratification within societies. The sermons of Ansaroul Islam appeals to the 'inferior minority' to break the status quo into a perfect, equal society. With class issues playing background music, some non-Fulani people have joined the insurgent group. Disregarding the traditional succession, Ansaroul uses religious claims to invalidate the power of domestic Imams and religious personalities. Again, Ansaroul has taken advantage of sentiments of counter-foreign, anti-state and ethnic origins to appeal to youths. Among the numerous messages in their sermons were the desire to end state taxes which had already received much attention in the unattended north (Estelle, 2019).

Making it more appealing, the teachings of Ansaroul blames the West for the woes of Burkina Faso, typically saying that Westerners are responsible for the economic inefficiencies of Burkina due to their extraction of the country's vast resources. Some teachings of the Ansaroul Islam stresses on the inferiority of the Fulani minority, using terms as 'Rimaibe of the whites' meaning, the under classed Fulani population. Already, the inferiority complex of the northern part is high as their expectations from the government are not met. Striking more radical Islamic messages into the ears of the 'supposedly' neglected class of Burkinabes ignites the acceptance and practice of Islamic extremism. With time, the ideologies become more violent and radical, giving chances for militant groups to break out (Estelle, 2019).

\section{Implementing Social Policies}

In addition to the appealing nature of Ansaroul Islamic teachings, the group is promoting a new social order. This commenced in northern Burkina Faso and is aimed at restructuring the Burkinabe society through religious teachings and violence. Basing their actions on religious reasons to halt events that will empower local authorities, and this has bee widely accepted by the poor within society. A perfect example is the stoppage of the practice of paying tokens to local authorities during marriage ceremonies. In most of these bans, the far-reaching benefits seem appreciable to the local people. As such, traditional and cultural preservation becomes a waste of time, rather, there is motivation to support the banning course.

Another way that Ansaroul is reshaping the society is promoting the extreme Islamic culture of restricting women. In detail, females are prevented from moving to football centers, smoking, enjoying ban music and encourages to put on the hijab (Estelle, 2019).

The group is also re-aligning the educational system of the north to suit their own culture and beliefs. Curriculums are being revised to replace French education with Islamic teachings. Strategies which are being adopted by the groups to reshape the 
society includes monetary offers and forceful activities. The group's activities is creating a social disorder and even those who accept the movement are often not able to involve themselves in certain traditional practices with genuine religious backings. The roots of the changing social order can be attributed to the forcible supremacy, coupled with the advantages which comes with these ideologies for the less recognized group of citizens (Estelle, 2019).

\section{Radical Islamic Ideology}

The Ansaroul pact of Islam appeals to the marginalized group of people through radical Islamic philosophies. Even though the group is purported to consist primarily of Fulani, this condition is just a result of regional concentration of Fulani in the Suom province. The origin of Ansaroul Islam cannot be traced on tribal basis but rather linked to pleasing radical messages which find the ears of resentful locals. Several individuals of lower social status believed to be youthful herdsmen of Fulani tribe and Rimaibe (believed to historical be a slave group of Fulani people) were attracted to the sermons of Dicko and ultimately joined his force. In effect, the hatred for normal social class disintegration probably explains why there are raids on traditional Islamic leaders within the Suom province (Le Roux, 2019).

\section{What are the responses to this emerging violence?}

The actions of Ansaroul Islam got to the table of Burkinabe government in August 2017, receiving 772 million dollar funding for the development of the Suom region. This was the apex period of the militant group and they seemed to gain the attention they required. The government knew that social infrastructure is inadequate in Suom province. Therefore, Paul Kaba Thiéba, Burkinabe Prime Minister during the period under review announced the purpose of the funds as for the construction of schools, roads and hospitals. The funds were disbursed in trenches, 13 million in 2017, 17 million in 2018 and 2019 receiving much more attention from the government. It is not only giving in to the demands and claims of Ansaroul Islam that underpins these moves by the government, rather the attempt to unpopularize the militant group by ensuring most citizens likely to join the group have no yet reason to do so. Earlier this year, Yirgou suffered disturbances between some ethnic groups, causing deaths and injuries. Claims have been made by civil advocates that, there has been no arrest in the post unrest period. This may be linked to the corrupt security agencies of Burkina Faso. The corrupt arms of these security forces have been claimed to release their anger on innocent settlements, bringing deaths and injuries to resident of these places and adding to the injuries left by the insurgents (Le Roux, 2019). Actions of security forces, in replying the Ansaroul bullying has become nothing less than a non-tactical move confirming the Ansaroul claims of neglecting some part of Burkina on basis of social 
infrastructural provision, including security. Violent security action is rather adding fuel to militant activities. Rather, security forces are advised to diplomatically team up with local settlers to uproot terrorism. It should be noted that many citizens have suffered by the hands of Ansaroul, laying the 'lack of confidence in government security' foundation in them. There is the need to provide peaceful security and strategically rolled out methods of completely sealing the possible resurface of insurgent jihadists and Ansaroul. This should be done together with local settlers. The key role that ought to be played by local leaders and the entire settlers in the smooth and calm fight against Ansaroul cannot be underestimated by the government (Le Roux, 2019). The Burkinabe government also rolled out a strategic instrument in 2015. This was the institution of the national observatory for the prevention and management of communal conflict with the objective of making social conflict resolution flexible. This observatory clearly has not been powerful and effective until now. Under its control, violent activities slip from captivity and showcase on the streets of Burkina. It, therefore, calls for refurbishment of the observatory by providing it with the necessary resources to fulfill its mandate by ensuring the cutting of support for Ansaroul by community leaders and activists.

\section{Conclusion}

The past decade has witnessed uprisings of terrorist activities in the Sahel region, spreading down to towards the coastal parts of sub-Saharan African. Ansaroul Islam originates from the northern Suom of Burkina Faso, making contacts with external bodies as Al-Qaeda and JNIM brotherhood and support from locally dissatisfied settlers. This disturbance has hindered the economic and social progress of Burkina, stimulating government response in the form of armed raids and observatory body set up. Notably, the contributory factors to the uprising come from social and economic inequalities. These factors give clues on how to tackle terrorism in Burkina as recommended below.

\section{Recommendations}

Following the roots of Ansaroul Islam and other militant activities in Burkina Faso, there are three basic ways which are recommended by this study to curb the situation. These recommendations are poverty reduction strategies, intensified educational policies and negotiations.

Education can be employed as a weapon for combating terrorism. First and foremost, education, intensified in all areas within the country will serve as disruptive methods in the breeding grounds of terrorist and extremist philosophies. Again, it is globally accepted to counter terrorism as a social policy in the wake of violence. This study will recommend that the education sector executes this strategy in two different ways. In the first place, educational projects will have to be rolled out to address the problems of social inequality and marginalization, especially in the Suom province of Burkina Faso. 
This will go a long way to rekindle the confidence of local settlers in the government and reduce their resentments to the state. Secondly, targets of education should be the segregated in the community. Curriculums designed to proportionately shape lives against terrorism and improve in technical and professional skills will reduce the rate at which young men join militant groups. In addition to these two, Counter-Terrorist Education programs can be introduced in different agencies such as the media, schools, churches and communal level to provide people with alternative ways to violence and reassure the marginalized groups of intended attention of government (de Silva, 2017).

Another way of countering terrorism is by negotiations. Well planned ways of negotiating with insurgents can also be employed by the Burkinabe government to solve the terrorism problem in the country. Democratic entities do frown on negotiation with terrorism due to the conception that it validates the actions of these insurgents and belittle the pursuers of peace. It is also believed that it gives a terrible pace and offsets global attempts at combating terrorist activities. However, proponents of the negotiation approach retort that these same democratic actors give in to negotiations when the need arises. Evidently, in 1991, the UK government agreed to the demands of the Irish Republican Army after an attack on 10 Downing Street. A similar thing happened in Spain in 1988 after a shop bombing by Basque Homeland and Freedom. Considering these hypocritic moves, the Burkinabe government can negotiate with Ansaroul Islam, not to offer its weakness but to show the readiness to settle for peace (Neumann, 2007).

Economic differences have been ,one-factor promoting acts of violence in the northern half of Burkina. Poverty is widespread in the northern sector. This situation should be tackled by looking at sustainable measures of offsetting the poverty outbreak in the country, especially within the Suom province. There are three generic frameworks within which this can be done. In the first place, the government can introduce livelihood programs through skills training and acquisition for the uneducated youth and women. Artisan works would be learned, and capital provided for individuals to start up. Secondly, primary (agro-based) enterprises could be initiated in the northern half. This will require empowering potential entrepreneurs to put their few resources and skills to use. Finally, the government can improve the private sector to absorb more of the idle youth. Additionally, the public sector can also be expanded to employ more citizens.

\section{References}

1. Antwi-Boateng, O. (2017). The Rise of Pan-Islamic Terrorism in Africa: A Global Security Challenge. Politics \& Policy, 45(2), 253-284.

2. Burnham, P., Lutz, K. G., Grant, W., \& Layton-Henry, Z. (2008). Research methods in politics. London: Palgrave Macmillan.

3. BussinesDay. (2019, March 21). Ghana, Togo and Benin on high alert against jihadist threat. BusinessDay. Retrieved from https://www.businesslive.co.za/bd/world/afri ca/2019-03-21-ghana-togo-and-benin-on-high-alert-against-jihadist-threat/. 
4. Center for International Security and Cooperation. (2018). Ansaroul Islam:Ansaroul Islam is an Islamic militant organization operating in Burkina Faso and neighboring countries. CISAC. Retrieved from https://cisac.fsi.stanford.edu/mappingmilitants/pro files/ansaroul-islam\#highlight_text_8396.

5. Collier, D. (1993). The comparative method. In Ada W. Finifter (Ed.), Political Science: The State of Discipline II (pp. 105-119). Washington D.C.: American Political Science Association.

6. Donati, J. (2018, September 5). U.S. Designates Mali-Based Militants as a Terrorist Group. The Wall Street Journal. Retrieved from https://www.wsj.com/articles/u-s-des ignates-mali-based-militants-as-a-terrorist-group-1536185152.

7. Estelle, E. (2019, May 9). How Ansar al Islam Gains Popular Support in Burkina Faso. CriticalThreats.org. Retrieved from https://www.criticalthreats.org/analysis/how-an sar-al-islam-gains-popular-support-in-burkina-faso.

8. Gurr, T. R. (1970). Why men rebel. NJ: Princeton University.

9. Human Rights Watch. (2019, March 22). "We Found Their Bodies Later That Day". Atrocities by Armed Islamists and Security Forces in Burkina Faso's Sahel Region. HRW. Retrieved from https://www.hrw.org/report/2019/03/22/we-found-their-bodieslater-day/atrocities-armed-islamists-and-security-forces.

10. Lijphart, A. (1971). Comparative politics and the comparative method. American Political Science Review, 65(03), 682-693.

11. Loada, A., \& Romaniuk, P. (2014). Preventing violent extremism in Burkina Faso toward national resilience amid regional insecurity. Goshen: Global Center on Cooperative Security.

12. Martin, G. (2015). Understanding terrorism: Challenges, perspectives, and issues. Thousand Oaks, CA: Sage Publications.

13. Nsaibia, H., \& Weiss, C. (2008). Ansaroul Islam and the Growing Terrorist Insurgency in Burkina Faso. Combating Terrorism Center. Retrieved from https://ctc.usma.edu/ansa roul-islam-growing-terrorist-insurgency-burkina-faso/.

14. Le Roux, P. (2019, July 29). Ansaroul Islam: The Rise and Decline of a Militant Islamist Group in the Sahel. Africa Center for Strategic Studies. Retrieved from https://africace nter.org/spotlight/ansaroul-islam-the-rise-and-decline-of-a-militant-islamist-groupin-the-sahel/.

15. Neumann, P. R. (2007). Negotiating With Terrorists. Foreign Affairs. Retrieved from https://www.foreignaffairs.com/articles/2007-01-01/negotiating-terrorists.

16. de Silva, S. (2017). Role of Education in Prevention of Violent Extremism. Washington, D.C.: World Bank Group.

17. The Soufan Group. (2019). Jihadist Terrorism Threatens to Destabilize Burkina Faso and Its Neighbors. The Soufan Group. Retrieved from http://www.soufangroup.com/ intelbrief-jihadist-terrorism-threatens-to-destabilize-burkina-faso-and-its-neigh bors/.

18. Tuman, J. S. (2003). Communicating terror: The rhetorical dimensions of terrorism. Thousand Oaks, CA: Sage Publications. 